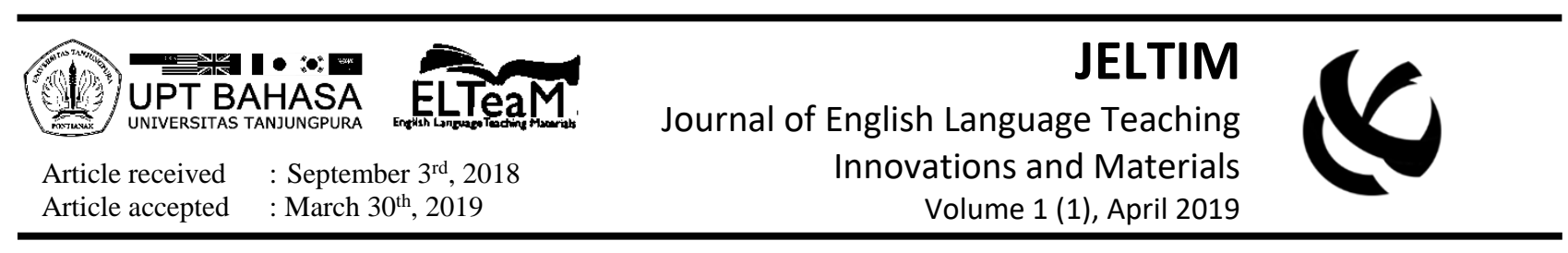

\title{
Discourse Features of Women's Language In The Social Media as Influenced by Formal Education
}

\author{
Maria Harumi Indrayani; Risa Rumentha Simanjuntak \\ Department of Humanities, Bina Nusantara University - INDONESIA \\ mariaharumi12@gmail.com
}

\begin{abstract}
This research has a purpose to find the ways women express themselves through written form in social media, relationship between educational backgrounds of women and their language choice, and the markers of the women's discourse. This research uses qualitative method by doing stratified random sampling and giving questionnaires. The data is analyzed by analyzing participants' language choice in social media post and formal education status, then finding the similarities and differences, analyzing the relation between participants' formal education status and their language choice in social media post, and analyzing the markers of women's discourse in social media. The results of this study found that some women uses coherence and cohesive consistently, while some women choose to have very casual writing style. This study confirms that women tendency to use more standard forms is more likely to be driven by their awareness of using proper language, rather than as a way of claiming such status (Holmes, 2008). Lastly, this study figured that women usually use intra-sentential code-switch more often and women's tendency to be more sensitive is the caused why women used a lot of adjective words related to feelings.
\end{abstract}

\section{Keywords}

Women, social media, educational background, Holmes, discourse

\section{INTRODUCTION}

Language variation happens because people express their ideas depending on their situations. Akmajian, Demers, Farmer and Harnish (1995) said that "no human language is fixed, uniform, or unvarying; all languages show internal variation" (p. 259). The amount of languages in the world are enormous but neither of it is altered instead it has its internal variety. One of the situations which affect language variation is social status.

In order to determine one's social status, many aspects have to be considered such as family background, formal academic achievement or current occupation. Socio-economic status is one of the achieved status examples which measuring one's position in social economic scale based on their education, income, type of occupation, place of residence, and in some populations, heritage and religion.

Experts' research shows that social status and gender does have connection. Women are more self- conscious about their social status in the society rather than men do. This statement was made based on the research with linguistic approach which result shows women uses more standard forms in speaking more than men. Women believes that the way they speak indeed determine their social status.

\section{THEORETICAL BACKGROUND}

The writer chooses four main theories for this research. First theory is discourse analysis. According to Thornbury (2005), "discourse analysis is the study of such language, and the analysis of the features and uses of texts - or text analysis - is an integral component of discourse analysis" (p. 7). Discourse analysis is basically part of language studies which involve deeper analysis of texts' attributes and functions. The distinction between discourse and text is to think of discourse as the process and text as the product. Furthermore, from discourse analysis, the writer chooses two subtheories which are coherence and cohesion. 
According to Van Dijk (1977), "Intuitively, coherence is a semantic property of discourse, based on the interpretation of each individual sentence relative to the interpretation of other sentences." (p. 93). Coherence is the underlying, overall meaning of a message, reflected through a dynamic process of text building, which includes both linguistic and pragmatic sources. Meanwhile, According to Jones (2012), "cohesion primarily has to do with linguistic features in the text, and coherence has to do with the kind of 'framework' with which the reader approaches the text and what he or she wants to use the text to do." (p. 49). The difference between cohesion and coherence is that cohesion deals with technical traits in relation to linguistic.

Second theory is sociolinguistics. According to Yule (2010), "the term sociolinguistics is used generally for the study of the relationship between language and society" (p. 254). Sociolinguists research further beyond the human language, instead they involve social factors in society. Furthermore, from sociolinguistics, there are three sub-theories that the writer chooses for the analysis purpose such as code-switching, features of women's language and explanation of women's linguistic behaviour.

Code-switching and code-mixing are often encountered during multilingual or bilingual conversations. There are three types of code-mixing which are inter-sentential, intra-sentential, and extrasentential. According to Lakoff (as cited in Holmes 2008, p. 298), women has their own speech characteristics. These characteristics are pointed out as listed below:

a) Lexical hedges or fillers, e.g. you know, sort of, well, you see.

b) Tag questions, e.g. she's very nice, isn't she?

c) Rising intonation on declaratives, e.g. it's really good.

d) "Empty" adjectives, e.g. divine, charming, cute.

e) Precise colour terms, e.g. magenta, aquamarine.

f) Intensifiers such as just and so, e.g. I like him so much.

g) "Hypercorrect" grammar, e.g. consistent use of standard verb forms.

h) 'Super polite' forms, e.g. indirect requests, euphemisms.

i) Avoidance of strong swear words, e.g. fudge, my goodness.

j) Emphatic stress, e.g. it was a BRILLIANT performance.

Meanwhile, the explanation of women's linguistic behaviour is taken from Holmes. According to
Holmes (2008), "the claim is that women are more aware of the fact that the way they speak signals their social class background or social status in the community" (p. 164). The use of standard language is one of the aspects to signal one's social status in society, hence women use standard language in their speech forms as a way of claiming higher status.

Second explanation of women's linguistic behaviour is woman's role as guardian of society's values. Based on Holmes (2008) statement, "the fact women use more standard forms than men point to the way society tends to expect 'better' behaviour from women than from men" (p. 165). Women whose connection with their children is undeniably closer than men, have big impacts to the growth of their children. Therefore, women are designated the role of modelling correct behaviour in the community especially when women are the role models for children's speech.

According to Holmes (2008), third explanation of the reasons behind women's use of standard language is "that people who are subordinate must be polite" (p. 166). Women's position in society as a subordinate group rather than men has created the image that women must speak carefully and politely.

Fourth explanation is that vernacular forms express machismo. Holmes (2008) stated, "the converse of this claim is that standard forms tend to be associated with female values and feminity" (p. 167). Women, whose characteristics are wellknown to be familiar to feminity, sets the common perception that standard language is rather women's thaw than men.

Third theory is socioeconomic status specifically in education factor. Education is not merely for direct purposes but indirect purposes such as to determine people socioeconomic status in society. According to Smith (2011), "education is a prerequisite to entry into occupations that carry higher prestige in the social system" (p. 22). In order to have a dignified occupation, one must achieve higher formal education, therefore one will be placed in top ladder of socioeconomic status measurement.

The fourth theory is social media. As stated from Junco and Chickering (2010), "social media are a collection of Web sites, services, and activities that engage users through collaboration, sharing, and democratization of roles and responsibilities" ( $p$. 12). Situated as one of the latest of several waves of new media, social media have introduced new communication patterns, created new forms of expression, and stimulated a wide civic participation.

\section{METHODOLOGY}

To conduct this research, the writer uses qualitative method. The application of qualitative 
method is through text analysis. Since this research deals with discourse features of women's language, therefore some aspects have to be concerned such as diction, coherence, cohesion and code-switching. Because this research needs groups of variety in the sample to also be representative, therefore the writer chooses to mix between random and stratified sampling into stratified random sampling. Furthermore, to complete participants' data, the writer will give questionnaires.

Participants of the research will be the Indonesian women within 20 - 30 years old. These women are selected based on their recent formal academic status and their writing in social media. The writer will choose 21 participants based on her acquaintances. Participants must be regularly updating their social media post which is contain image and caption written by themselves in English.

The material of this research are written posts in social media and results of questionnaires. The questionnaires are the personal data about participants which contain questions such as their latest formal academic achievement, outcome, and occupation which determine their socioeconomic status. The criteria of choosing participants' social media post relies on the language that they used, the length of the posts and the originality of social media posts' caption. For this research, the selected posts must be written in English, contained minimum one sentence and written by the participants itself.

The original idea of this research comes from Janet Holmes' statement that women's speech cues their place in social strata. The writer wants to prove the validity of this statement. Then the writer finds linguistic theories that she finds suitable for this research, which are discourse analysis and sociolinguistic. From discourse analysis, the writer chooses two theories such as coherence and cohesion. Then from sociolinguistic, the writer also chooses two theories such as explanation of women's linguistic behaviour and code-switching. Then the writer starts to find the participants that match with the requirements and select the participants based on their latest formal education status. After that, the writer chooses only one post from each of participants' social media to be analysed. Finally, the writer collects all of 21 selected women's social media post as material for this research.

The first step of the analysis is to re-write the selected posts into separate sentences in order to have an in-depth analysis. The second step is to categorize the coherence relation between sentences of the posts by listing coherence relation that the writer finds in the posts. The third step is to categorize the topic and comment of the posts by putting the topic and comments in table. Then the fourth step is to find the cohesive devices used in the posts by listing and explaining cohesive devices that the writer finds in the posts. After that, the fifth step is to categorize women's language characteristics such as code-switching, slang words, and markers of women's discourse. Then the last step is to write the final conclusion

\section{RESULTS AND DISCUSSION}

\section{Language Expression of Women in Written Form}

First group analysis reveals that coherence relation is used by only four out of seven people in the group, then there are only four people whose topic of their posts are explicitly stated, however all respondents in first group uses at least one of cohesion categories, and lastly there are only two people who uses code-switching on their posts.

In second group, the analysis results are more stable than first group. The coherence relation is used by six out of seven people in second group, then topic of posts is explicitly stated in each of their post, and six out of seven people in second group uses at least one of cohesion categories, last but not least there are two people who uses code-switching on their post.

In third group, the analysis results are varied rather than first and second group. The coherence relation is used explicitly by only four out of seven people in this group. Meanwhile, topic of the posts is stated by five out of seven people and the cohesion categories are used only by four out of seven people in this group and last but not least, the amount of code-switching is the highest in this group rather than previous groups which include four out of seven people.

\section{The Relationship between Educational Backgrounds of Women with Their Use of Language}

The use of language is being identified through the application of coherence and cohesion. The differences will be seen further by comparing each group's educational background. Based on the analysis of social media posts by 21 women in previous chapter, there are some resemblances and contrasts found from three groups.

The resemblance between three groups is they relatively states topic and comments of their posts even though there are some correspondents whose topic is not stated clearly in their post. Through micro-coherence lens, only the second group which have the larger amount of people uses it correctly according to the theory. Meanwhile, in first and second group only about half people of each group who uses micro-level coherence correctly. 
Through the categories of cohesion, first and second group applies the theory correctly, despite there is one correspondent who does not use any of cohesion categories. On the other side, only four out of seven people who applies at least one of cohesion categories. Anyhow, the number of correspondents who do code-switching is the biggest in third group amongst other groups.

The results show second group, which is categorized for women who are graduated with bachelor degree, for appearing to be most coherent and cohesive in their posts amongst first and third group. This result is may be affected by the urge to show that their language choice even in informal platforms such as social media are suitable with their education status as postgraduate.

Meanwhile, first group, which is categorized for women who are pursuing their bachelor degree, is appearing to be the less coherent in their posts amongst second and third group because half of this group do not use coherence correctly but cohesion is used by all of correspondents in this group correctly. This result is may be affected by their very casual style in writing in the social media.

The third group which contains with women who are pursuing their master degree has a minimum amount of both coherence and cohesion applied in their posts. This result may be affected by two possibilities; first possibility is that third group's correspondents may have chosen occupation field outside of education, therefore they are prone to use more conversational English rather than Academic English, and then second possibility is that the correspondents are not driven by the urge to show off their knowledge in correct written English.

Having seen the difference between the uses of language, further discussion will be seen through women's educational background. This can be enriched by taking consideration on the women's expenditure per month and occupational status. The main categorization is based on formal education background. Other categorizations, such as one based on occupation status and expenditure, has low reliability due to the lack of correspondent's income information, in order to define each correspondent's socioeconomic status.

\section{The Markers of The Women's Discourse}

Based on selected posts of chosen correspondents, leisure, family issues and celebration are the most used topic that the correspondents have chosen to write in social media. However, markers are found on their posts beside the use of coherence and cohesion such as code-switch, slang and shortened sentences. There are also some words or expression that identically used by women in the topics as mentioned before.

All groups have its own correspondents who use code-switch in their posts. Third group has four out of seven correspondents who use code switch which makes this group as the biggest user of code switch amongst first and second group which each of it only has two out of seven correspondents that use code switch. Inter-sentential code-switch that the correspondents use mostly between Indonesian and English and vice-versa, and only one correspondent who use code-switch between Korean and English. The following table is the list of Inter-sentential code-switching used in posts:

\begin{tabular}{|c|c|c|}
\hline No & Name & $\begin{array}{l}\text { Inter-sentential Code- } \\
\text { Switching }\end{array}$ \\
\hline \multirow[t]{4}{*}{1.} & \multirow[t]{4}{*}{$\begin{array}{l}\text { Shavira Ayashita } \\
\text { (@viraayashita) }\end{array}$} & $\begin{array}{l}\text { - Aku tidak bermaksud } \\
\text { menipu dengan pakai } \\
\text { makeup. } \\
\text { - } \mathrm{OK}, \text { here is the thing. }\end{array}$ \\
\hline & & $\begin{array}{l}\text { - I've got passion in it. } \\
\text { - Aku suka coba-coba } \\
\text { make-up gaya ini gaya } \\
\text { itu. }\end{array}$ \\
\hline & & $\begin{array}{l}\text { - It's a hobby and it's fun. } \\
\text { - Aku bahagia }\end{array}$ \\
\hline & & $\begin{array}{l}\text { - He never complains. } \\
\text { - Dia tau aku suka } \\
\text { melakukan ini. }\end{array}$ \\
\hline \multirow[t]{3}{*}{2.} & \multirow[t]{3}{*}{$\begin{array}{l}\text { Vini Deliana } \\
\text { Deulay } \\
\text { (@vinidaulay) }\end{array}$} & 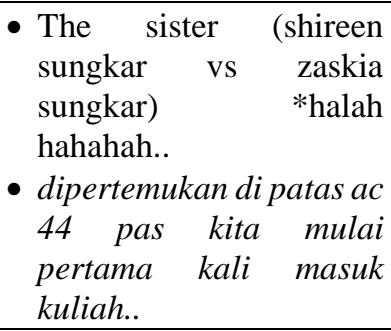 \\
\hline & & $\begin{array}{l}\text { - she's my best listener and } \\
\text { advisor.. dan best "mak } \\
\text { comblang" in this world } \\
\text { ahhahaaaa } \\
\text { - walaupun sok2an bgt ga } \\
\text { mau bantuin tp } \\
\text { ujung2nya doi juga } \\
\text { turun tangan }-(-): 0\end{array}$ \\
\hline & & $\begin{array}{l}\text { - see you in another } \\
\text { dadakan meet up } \\
\text { sistaaaaa! } \\
\text { - at least niatan ke dufan } \\
\text { bisa tercapai (kudu } \\
\text { tercapai) yaaahhh } \\
\end{array}$ \\
\hline
\end{tabular}




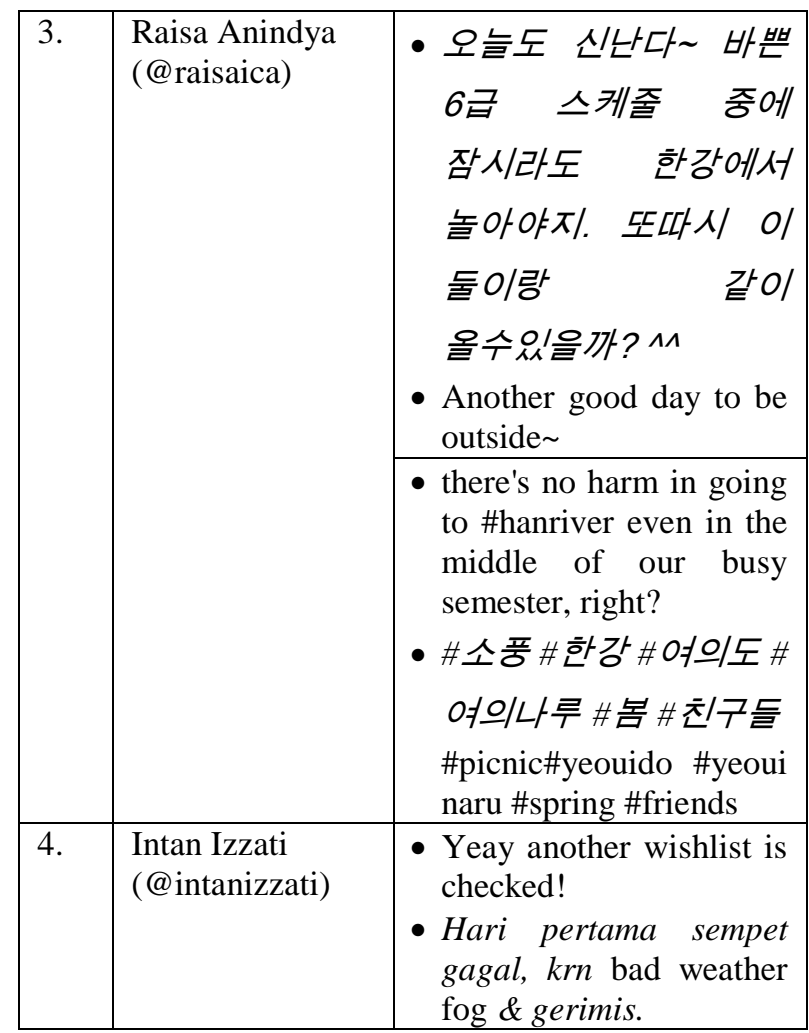

Table 1 List of Inter-Sentential Code-Switch

Then intra-sentential code-switch is also used by some correspondents between Indonesian to English or English to Indonesian, Javanese to English, and Arabic to Indonesian. The following table contains of intra-sentential code-switch words or phrases:

\begin{tabular}{|l|l|l|l|}
\hline No. & Word/Phrase & \multicolumn{1}{|c|}{ Origin } & \multicolumn{1}{|c|}{ Meaning } \\
\hline 1 & Make Up & English & $\begin{array}{l}\text { Cosmetics such } \\
\text { as lipstick or } \\
\text { powder applied } \\
\text { to the face } \\
\text { used to } \\
\text { enhance or } \\
\text { alter the } \\
\text { appearance }\end{array}$ \\
\hline 2 & Natural & English & $\begin{array}{l}\text { Existing in or } \\
\text { caused by } \\
\text { nature; not } \\
\text { made or caused } \\
\text { by humankind. }\end{array}$ \\
\hline 3 & Kak & Indonesian & $\begin{array}{l}\text { Nickname for } \\
\text { older sister or } \\
\text { brother }\end{array}$ \\
\hline 4 & Bapak/Bapa & Indonesian & Father \\
\hline 5 & $\begin{array}{l}\text { Matur } \\
\text { Suksma }\end{array}$ & Balinese & Thank you \\
\hline
\end{tabular}

\begin{tabular}{|l|l|l|l|}
\hline 6 & Dan & Indonesian & And \\
\hline 7 & $\begin{array}{l}\text { Mak } \\
\text { Comblang }\end{array}$ & Indonesian & Match-maker \\
\hline 8 & Dadakan & Indonesian & All of a sudden \\
\hline 9 & $\begin{array}{l}\text { Bad Weather } \\
\text { Fog }\end{array}$ & English & $\begin{array}{l}\text { A fog that is } \\
\text { caused by } \\
\text { disastrous } \\
\text { weather }\end{array}$ \\
\hline 10 & Hamdalah & Arabian & Thank God \\
\hline
\end{tabular}

Table 2 Diction Used in Intra-Sentential CodeSwitch

Extra-sentential code-switch is also used by some correspondents, the following table is the list of extra-sentential code-switch words mentioned in the posts:

\begin{tabular}{|l|l|l|}
\hline No. & \multicolumn{1}{|c|}{ Words } & \multicolumn{1}{c|}{ Meaning } \\
\hline 1 & Hm & An expression of sighing \\
\hline 2 & Halah & An expression of shyness \\
\hline
\end{tabular}

Table 3 Diction Used in Extra-Sentential Code-

Switch

Slang words/phrases are also mentioned several times in correspondents' post, the following table is the list of slang words/phrases:

\begin{tabular}{|c|l|c|c|l|}
\hline No & Markers & $\begin{array}{c}\text { Partici } \\
\text { pants }\end{array}$ & $\begin{array}{c}\text { Frequ } \\
\text { ency }\end{array}$ & \multicolumn{1}{|c|}{ Topic } \\
\hline 1 & Dream & 2 & 4 & $\begin{array}{l}\text { Empowerment, } \\
\text { Celebration }\end{array}$ \\
\hline 2 & Beautiful & 2 & 2 & $\begin{array}{l}\text { Empowerment, } \\
\text { Make-Up }\end{array}$ \\
\hline 3 & Happy & 8 & 8 & $\begin{array}{l}\text { Empowerment, } \\
\text { Celebration, } \\
\text { Make-Up, } \\
\text { Surprise, } \\
\text { Reunion }\end{array}$ \\
\hline 4 & Happiness & 4 & 4 & $\begin{array}{l}\text { Celebration, } \\
\text { Personal } \\
\text { Thoughts }\end{array}$ \\
\hline 5 & Love & 3 & 4 & $\begin{array}{l}\text { Make-Up, } \\
\text { Celebration, } \\
\text { Surprise }\end{array}$ \\
\hline 6 & Mama & 2 & 2 & Celebration \\
\hline 7 & Thank you & 3 & 7 & $\begin{array}{l}\text { Surprise, } \\
\text { Celebration, } \\
\text { Separation }\end{array}$ \\
\hline
\end{tabular}

Table 4 Diction Used in Slang 
There are some words that identical with women's discourse in particular topics. Since majority of the posts' topic relates to informal events, there are some repeated words or phrases used by participants which show a particular characteristic of women's discourse. The following table is a list of words or phrase found several times in participants' post:

\begin{tabular}{|c|c|c|c|}
\hline No. & Word/Phrase & Proper Forms & Meaning \\
\hline 1 & Cray & Crazy & $\begin{array}{l}\text { Extremely } \\
\text { enthusiastic }\end{array}$ \\
\hline 2 & Gal & Girl & $\begin{array}{l}\text { A young or } \\
\text { relatively } \\
\text { young } \\
\text { female }\end{array}$ \\
\hline 3 & Yum & Yummy & $\begin{array}{l}\text { An } \\
\text { expression } \\
\text { for delights }\end{array}$ \\
\hline 4 & Being-ness & Well-being & $\begin{array}{l}\text { The state of } \\
\text { being } \\
\text { comfortable, } \\
\text { healthy or } \\
\text { happy }\end{array}$ \\
\hline 5 & The uni & The university & $\begin{array}{l}\text { An } \\
\text { institution of } \\
\text { higher } \\
\text { education } \\
\text { and research } \\
\text { which grants } \\
\text { academic } \\
\text { degrees in } \\
\text { various } \\
\text { subjects }\end{array}$ \\
\hline 6 & Bumbum & Backside & $\begin{array}{l}\text { Lower } \\
\text { backside of } \\
\text { human body }\end{array}$ \\
\hline 7 & Sista & Sister & $\begin{array}{l}\text { A woman or } \\
\text { girl in } \\
\text { relation to } \\
\text { other } \\
\text { daughters } \\
\text { and sons of } \\
\text { her parents }\end{array}$ \\
\hline 8 & Babe & Baby & $\begin{array}{l}\text { A very } \\
\text { young child, } \\
\text { especially } \\
\text { one newly or } \\
\text { recently } \\
\text { born. }\end{array}$ \\
\hline
\end{tabular}

Table 5 Markers of Women's Discourse social media. Women express themselves on written forms in social media variously. According to this research results', there are some participants whose posts are not coherent or cohesive, or even, neither coherent nor cohesive. Meanwhile, there are also some participants whose posts appears to be both coherent and cohesive.

Second conclusion of this research differs with a concept which written by Holmes (2008) that stated, "women use more standard speech forms as a way of claiming such status" (p. 164). It is believed that women have tendency to use more standard forms in order to show that they belong in higher social class. On the contrary, the results of this research show that the group with the lowest educational background (first group which contains women who are pursuing their bachelor degree) in this research to be the least coherent in their posts. This result is may be affected by their very casual style in writing in the social media. Meanwhile, the group with the middle educational background (second group which contains women who are graduated as postgraduate) in this research appears to be the most coherent and cohesive in their posts. This result may be affected by the urge to show that their language even in informal platforms such as social media are suitable with their education status as postgraduate.

Third conclusion involves explanation of the markers of women's discourse. Based on the results, in the social media, women usually use intrasentential code-switch more often rather than intersentential and extra-sentential code-switch. The diction that women used in social media also supports the theory of English as sexist language by Janet Holmes (2008). Based on the frequency of each of feminine words mentioned in the posts, the word "happy" is the most used word. This result may be associated by women's tendency to be more sensitive than the opposite gender, therefore women used a lot of adjective words related to feelings more often.

For future researcher, the writer wants to give some suggestions related to this topic. In order to expand the discovery, future researcher may need to increase the amount of participants involved. The bigger amount of participants involve in this research, the results may become more various especially when it comes to deterime the marker of women's discourse.

\section{REFERENCES}

Akmajian, A., Demers, R., Farmer, Ann K., \& Harnish, R. (1995). Linguistics: An Introduction to Language and 
Communication. $4^{\text {th }}$ ed. Cambridge, Mass.: MIT Press.

Dijk, T. (1977). Text and Context. London: Longman.

Holmes, J. (2008). An introduction to sociolinguistics. Harlow, England: Pearson Longman.
Jones, R. (2012). Discourse Analysis. Milton Park, Abingdon, Oxon: Routledge.

Thornbury, S. (2005). Beyond the Sentence. Oxford: Macmillan Education.

Yule, G. (2010). The Study of Language. $4^{\text {th }} \mathrm{ed}$. Cambridge, UK: Cambridge University Press 
